\title{
Acoustic Doppler Velocity Monitoring Within Main Spring, Barton Springs, Austin, Texas, April-September 2004- Enhancing the Accuracy of Springflow Data
}

Acoustic Doppler velocity (ADV) meters are sophisticated underwater monitoring instruments that use sound waves to measure water velocity in as many as three directions. In April 2004, an ADV meter was installed inside the principal orifice and discharge point of Main Spring at Barton Springs in Austin, Texas. This instrument collects velocity data that can be used to enhance the accuracy of springflow data and identify previously unrecognized hydrologic patterns.

\section{Daily Mean Springflow}

The U.S. Geological Survey (USGS), in cooperation with the City of Austin, has collected and published daily mean springflow for station 08155500 Barton Springs at Austin, Texas (Aragon Long and others, 2005), from March 1, 1978, to the present. A geographic overview of Barton Springs is shown in figure 1. The flow from Barton Springs is the combined flow of Eliza Spring, Old Mill Spring, and Main Spring. The flow of Upper Barton Spring is not included. Most of Barton Springs flow emerges from Main Spring, which is located within the Barton Springs swimming pool about mid-length along the south or right bank (figs. 1, 2). The photograph in figure 2 shows the pool level down several feet for cleaning. Continuous monitoring of springflow at Barton Springs is important because the springs are a major discharge point of the Barton Springs segment of the Edwards aquifer. The springs serve as a major source of drinking water, recreation, and endangered species habitat in Central Texas.

The daily mean springflow data published by the USGS for station 08155500 represent the longest continuous record of water-quantity information available for Barton Springs. Historically, the daily mean springflow has been computed using the daily mean gage height derived from continuous 15 -minute observations of gage height and a stage-discharge relation developed for the station. The stage-discharge relation is developed by using aquifer water levels measured near the spring orifice in a nearby monitoring well (YD 58-42-903) and manual discharge measurements of Barton Springs flow. The aquifer water levels are used as the gage height for the station. Gage height and additional parameters are recorded by a USGS Data Collection Platform (DCP) at the monitoring well, which is located about $100 \mathrm{feet}(\mathrm{ft})$ south of Main Spring on the south or right bank of Barton Creek (fig. 2). Currently (2005), the DCP transmits data at 4-hour intervals to a geostationary operational environmental satellite (GOES). The data are relayed through various telecommunication networks, delivered to a USGS National Water Information System (NWIS) server for processing through the stage-discharge relation, and made available on USGS Internet servers. Realtime gage height, discharge, and other parameters can be viewed at http://waterdata.usgs.gov/tx/nwis/uv/?site_no= 08155500\&PARAmeter_cd=00065,00060. A graph of gage height and springflow from April 1, 2004, to September 30, 2004, is shown in figure 3. In general, larger springflow is associated with higher gage height. The periods in which the association is ambiguous or even reversed are the subject of this report.

The specific stage-discharge relation for Barton Springs is an empirically developed relation that transforms gage height to springflow for specific water levels of the swimming pool. The relation is routinely verified and refined through periodic (manual) measurement of springflow. The relation represents a critical step in the process of computing daily mean springflow (Sauer, 2002).

The periodic manual measurement of springflow at Barton Springs requires three nearly contemporaneous discharge measurements on and near Barton Creek: (1) discharge of Barton Creek below the downstream dam of the pool (fig. 1), (2) discharge of Old Mill Spring, which also is downstream from the pool, and (3) discharge of Barton Creek at a site upstream from the pool and downstream from Upper Barton Spring. Discharges (1) and (2) are added and discharge (3) is subtracted from the sum to yield the flow from Main, Eliza, and Old Mill Springs, which collectively is referred to as Barton Springs flow and reported for station 08155500.

About 200 periodic springflow measurements by the USGS since 1958 have provided data to develop a stage-discharge

An accurate record of springflow at Barton Springs is important for several reasons. First, Barton Springs is the only known habitat for the Barton Springs salamander (Eurycea sosorum), a federally-listed endangered species that is dependent on reliable springflow to survive. Determination of sustainable Edwards aquifer yields compatible with the survival of the species is impossible without an accurate springflow record. Second, the 3-acre swimming pool fed by Barton Springs is enjoyed by about 340,000 people per year (2003) and is an important tourist attraction. Third, Barton Springs provides a part of Austin's municipal water supply; water from Barton Springs discharges into Town Lake on the Colorado River about 0.4 mile upstream from one of Austin's three water-supply plants. Fourth, flow in Barton Springs reflects water levels in the Barton Springs segment of the Edwards aquifer, which currently (2005) is designated a sole-source aquifer by the U.S. Environmental Protection Agency.

This report, prepared by the U.S. Geological Survey, briefly summarizes the results of recent ADV-based velocity and springflow data acquisition at Barton Springs and describes an application of velocity monitoring to enhance the accuracy of springflow data. 
relation for normal pool (poolfull) levels. The definition of pool-full level is ambiguous and is known to change with historical pool operation. Water pressure proportional to the level of the pool, where most springflow emerges, has substantial influence on computed flow from Barton Springs. At both scheduled and unscheduled times, water levels in the pool are changed at the dam by pool staff or changed because of overtopping stormflow in unpredictable amounts as part of typical pool operation, maintenance, and Barton Creek

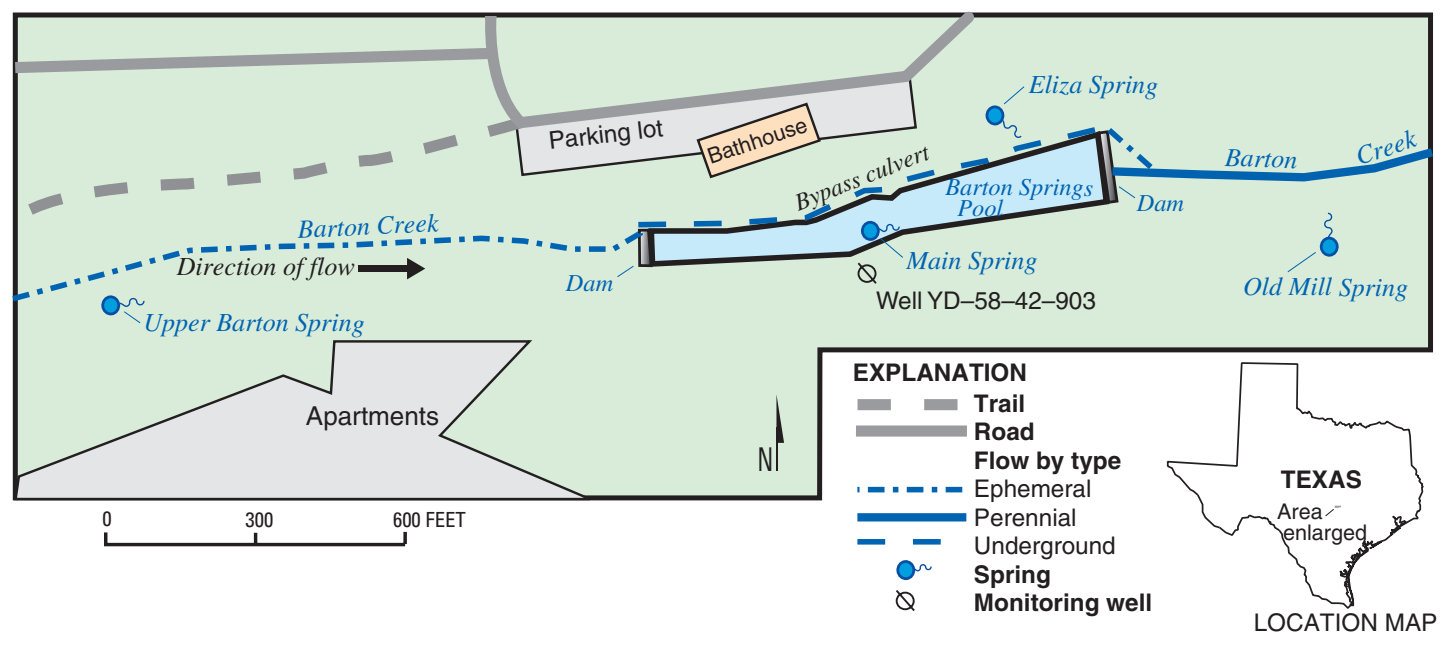

Figure 1. Barton Springs swimming pool, associated springs, and ancillary elements for springflow monitoring, Austin, Texas.

stormflow accommodation. Complicating matters further, leakage to, or inflow from, the Barton Creek bypass culvert (fig. 1) also influences pool levels. Experience has shown that the stage-discharge relation "shifts," which means that subtle changes in pool levels produce detectable changes, or shifts, in the stage-discharge relation. The shifts necessitate adjustments to the stage-discharge relation to maintain accuracy of the daily mean springflow record.

The sensitivity of the stage-discharge relation to pool level implies that periodic measurement of springflow always will be necessary to produce reliable springflow data. The sensitivity also implies that when unpredictable stormflows on Barton Creek are larger than the bypass can convey, which results in some of the stormflow passing through the pool, the stage-discharge relation is not applicable. Stormflow typically increases pool levels by several feet and sometimes in excess of $10 \mathrm{ft}$ for brief intervals. Furthermore, on a semi-regular basis, the pool is temporarily drawn down several feet for several hours to several days for cleaning and other maintenance activities, which often immediately follow stormflows. The stage-discharge relation is not applicable during these periods. During periods when the stage-discharge relation is not applicable, typically the two (valid) period-bounding daily mean springflow values are prorated by straight-line interpolation for each day of the period.

\section{Velocity Data for Estimation of Daily Mean Springflow}

Experimental velocity data (not reported here) collected by USGS divers at an arbitrary location within the Main Spring orifice during September 23-25, 2003, a period of major pool drawdown, showed that the velocity of water flowing from the orifice increased about 40 percent during the lowered pool condi-

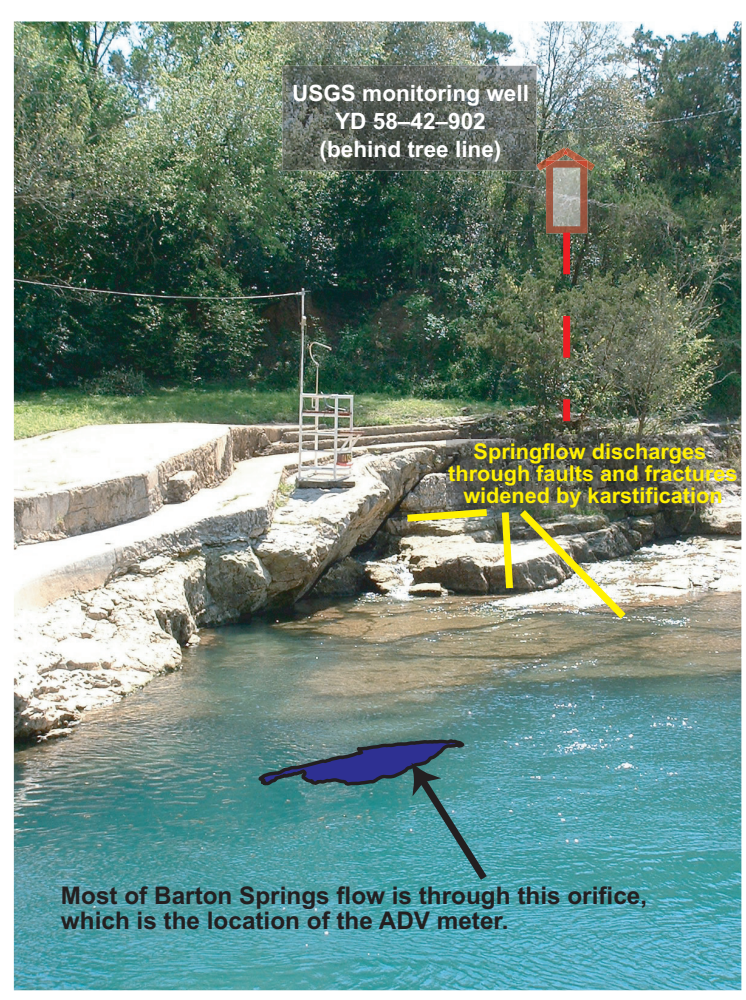

Figure 2. Main Spring and approximate location of orifice and monitoring well. tions. The velocity increase was expected because of less water depth in the pool (hydraulic head at the orifice). Interpretation of the velocity data strongly indicated that the proration method could be enhanced with a complementary method based on velocity-indexing the springflow for periods when the stage-discharge relation is not applicable. If the ratio of springflow measured in cubic feet per second $\left(\mathrm{ft}^{3} / \mathrm{s}\right)$ to velocity measured in feet per second (ft/s) can be estimated, then multiplication of this ratio-the "discharge/index-velocity ratio" in units of square feet $\left(\mathrm{ft}^{2}\right)$ - by daily mean velocity would produce an improved estimate of the daily mean springflow.

To apply the discharge/index-velocity ratio, on April 1, 2004, USGS divers installed a three-dimensional acoustic Doppler velocity (ADV) meter on the ceiling of the Main Spring orifice.

The ADV meter has a combined communication and power cable, which surfaces below a lifeguard tower near the orifice (fig. 2) and is connected to the DCP at the station. At 4-hour intervals, the DCP transmits sixteen 15-minute values of $\mathrm{x}-, \mathrm{y}-$, and $\mathrm{z}$-velocity, and acoustic signal strength. Each 15-minute value is computed by 5 -minute averaging. The near real-time velocity data can be viewed at http://waterdata.usgs.gov/ tx/nwis/uv?dd_cd=24\&format= gif\&period=7\&site_no=08155500.

The z-component of the velocity data is the speed of the water at a point about $8 \mathrm{ft}$ inside the orifice and is aligned with the principal flow direction (out of the orifice). The z-component velocity is used for velocity in this report. (Normally, the $\mathrm{x}$-component velocity is used in ADV applications, but the geometric characteristics of the Main Spring orifice required an alternative instrument installation.) To appropriately use the discharge/index-velocity ratio, additional springflow measurements are 
needed during and immediately after periods when the pool is substantially below or above the pool-full level. The discharge/index-velocity ratio likely will show limited variation with changes in both aquifer and pool levels, because the basic geometric configuration of the fractured limestone from which springflow emerges does not change with time.

\section{Summary of Periods of Daily Mean Springflow Estimation}

During April 1 to September 30, 2004 (183 days), the cumulative springflow of Barton Springs exceeded 8.8 billion gallons, and seven periods occurred during which the stage-discharge relation was not applicable. The periods totaled 21 days. For each (or parts) of the 21 days the stage-discharge relation was not applicable, and the daily mean streamflow for each day requires estimation. A time-series graph summarizing the April 1 to September 30, 2004, period is shown in figure 4. The velocity data were filtered and smoothed to more clearly show temporal trends; occasional unrealistically small velocity spikes in the data thus were suppressed. In general, the velocity data show considerable correlation with the daily mean springflow from the stage-discharge relation. Increasing velocity generally is associated with increasing springflow. According to the data, when springflow exceeds about $60 \mathrm{ft}^{3} / \mathrm{s}$ and the pool is full, the separation between the velocity and the daily mean springflow increases, which indicates that the discharge/index-velocity ratio increases.

Details of the daily mean springflow estimation for the seven periods noted in figure 4 follow.

Period 1, April 29 and 30, 2004-The daily mean springflows for these two poolmaintenance days (fig. 4) were estimated using a discharge/index-velocity ratio of 40 $\mathrm{ft}^{2}$ and the daily mean velocity for each day. The estimated values for these two days are slightly larger than if the daily values had been estimated through proration with April 28 and May 1 springflows. A summary of the estimation is listed in table 1.

Period 2, June 9-18, 2004 (June flood) - The daily mean springflows for these 10 days (fig. 4) were estimated using a discharge/index-velocity ratio of $37.6 \mathrm{ft}^{2}$. This ratio was assumed applicable because $37.6 \mathrm{ft}^{2}$ is the ratio of a direct measurement of springflow $\left(90 \mathrm{ft}^{3} / \mathrm{s}\right)$ on June 16,2004 , and contemporaneous velocity data from the ADV meter in Main Spring. The pool was drawn down several days by City of Austin staff for removal of flood debris and general pool cleaning. A detailed time series for the June 9-18, 2004, period is shown in figure 5 and includes both recorded velocity data and the filtered and smoothed velocity data. Using the velocity data, the additional volume of springflow for the 10 days is about 117 million gallons (shaded region in fig. 5).

Period 3, June 30-July 4, 2004 (July flood) - The daily mean springflows for these 5 days (fig. 4) were estimated using an assumed discharge/index-velocity ratio of $37.6 \mathrm{ft}^{2}$ from the June 16, 2004, springflow measurement.

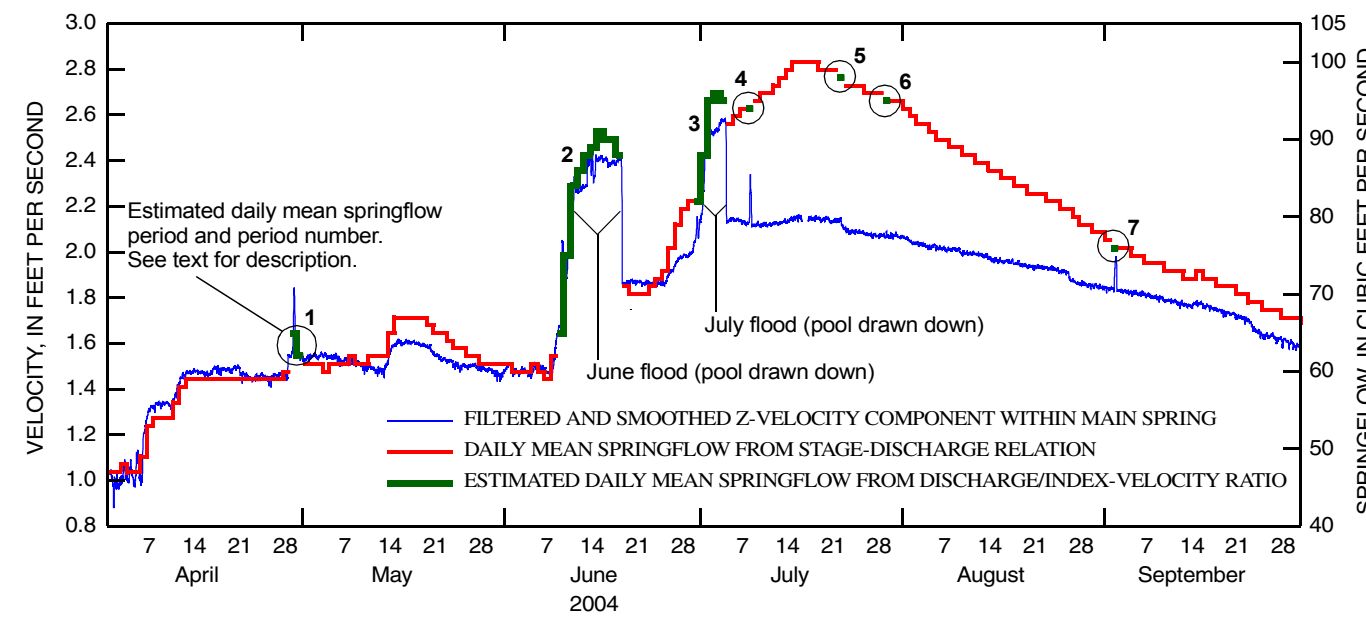

Figure 4. Comparison of z-component of velocity within Main Spring, daily mean springflow derived from stage-discharge relation, and estimated daily mean springflow for 08155500 Barton Springs at Austin, Texas, April 1-September 30, 2004.

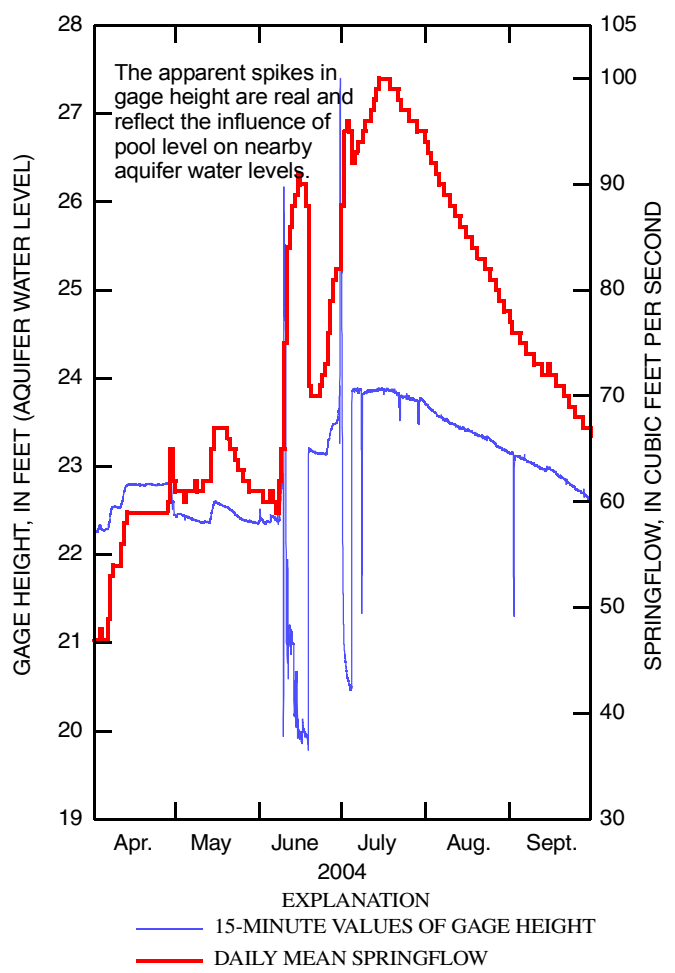

Figure 3. Comparison of gage height and computed and estimated daily mean springflow for 08155500 Barton Springs at Austin, Texas, April 1September 30, 2004.

Table 1. Estimation of daily mean springflow using discharge/index-velocity ratio and daily mean velocity [ft/s, feet per second; $\mathrm{ft}^{2}$, square feet; $\mathrm{ft}^{3} / \mathrm{s}$, cubic feet per second; --, not available; e, estimated by multiplying $40 \mathrm{ft}^{2}$ by daily mean velocity.]

\begin{tabular}{lccc}
\hline Date & $\begin{array}{c}\text { Daily mean } \\
\text { velocity } \\
(\mathrm{ft} / \mathrm{s})\end{array}$ & $\begin{array}{c}\text { Discharge/index- } \\
\text { velocity ratio } \\
\left(\mathrm{ft}^{2}\right)\end{array}$ & $\begin{array}{c}\text { Daily mean } \\
\text { springflow } \\
\left(\mathrm{ft}^{3} / \mathrm{s}\right)\end{array}$ \\
\hline April 28 & 1.49 & 40 & 60 \\
April 29 & 1.63 & -- & $\mathrm{e} 65$ \\
April 30 & 1.56 & -- & $\mathrm{e} 62$ \\
May 1 & 1.53 & 40 & 61 \\
\hline
\end{tabular}

Periods 4-7, July 8, 2004; July 22, 2004; July 29, 2004; and September 2, 2004-The daily mean springflows for these 4 days (fig. 4) were estimated by proration and not the discharge/index-velocity ratio because the drawdown was brief and not substantial enough to appreciably increase velocity for long. These days were regularly scheduled pool cleaning days, and the stage-discharge relation was not applicable for the entire day.

\section{Additional Observations}

Some additional observations of the velocity data were made. The velocity data show a curious and as 
yet unexplained daily variation on April 3-5, 2004 (fig. 6), during the end of a period of lower than average springflow. The average springflow during March and April is about $68 \mathrm{ft}^{3} / \mathrm{s}$. For 3 consecutive days, the velocity was maximum in early afternoon and minimum in early morning - a 24-hour cycle is evident. The daily variation in velocity indicates that springflow also has daily variation (assuming that the ratio between springflow and velocity [discharge/indexvelocity ratio] is constant for a given day). These data are believed to be the first evidence to indicate the possibility of potentially daily cyclical springflow at Barton Springs. The daily velocity variation is not apparent for the remainder of the reporting period, April 6-September 30, 2004. The source for the daily velocity (and possibly springflow by association) variation could be natural or anthropogenic.

\section{Summary}

The ADV meter has provided scientifically informative, realtime velocity data from within the orifice of Main Spring in the Barton Springs swimming pool for the period April 1, 2004, to September 30, 2004. During this period, the daily mean springflow required periodic estimation because the conventional stagedischarge relation is not applicable during periods of pool drawdown or Barton Creek stormflow. A discharge/index-velocity ratio (ratio of springflow to velocity) can be used with the velocity data to estimate daily mean springflow; this method was used for 17 of 21 days for the April 1-September 30, 2004, reporting period. Although the discharge/index-velocity ratio requires further study, the accuracy of springflow estimation at Barton Springs can be enhanced with ADV measurements relative to the traditional straight-line proration method. Finally, additional observations of

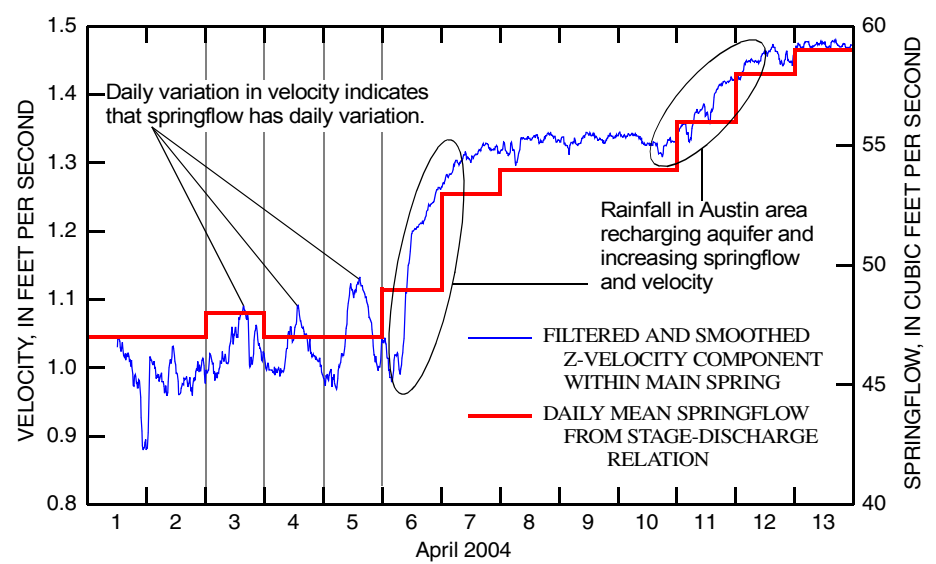

Figure 6. Comparison of z-component of velocity within Main Spring and daily mean discharge derived from stage-discharge relation for 08155500 Barton Springs at Austin, Texas, April 1-13, 2004.

the data indicate that cyclical daily variation in velocity and hence springflow from the Edwards aquifer possibly occurs at Barton Springs.

\section{Selected References}

Aragon Long, S.C., Reece, B.D., and Eames, D.R., 2005, Water resources data, Texas, water year 2004-Volume 4: U.S. Geological Survey Water-Data Report TX-04-4, 363 p.

Morlock, S.E., Nguyen, H.T., and Ross, J.H., 2002, Feasibility of acoustic Doppler velocity meters for the production of discharge records from U.S. Geological Survey streamflow-gaging stations: U.S. Geological Survey Water-Resources Investigations Report 01-4157, $56 \mathrm{p}$.

Sauer, V.B., 2002, Standards for the analysis and processing of surfacewater data and information using electronic methods: U.S. Geological Survey Water-Resources Investigations Report 01-4044, 91 p.

Senger, R.K., Collins, E.W., and Kreitler, C.W., 1990, Hydrogeology of the northern segment of the Edwards aquifer, Austin region: The University of Texas at Austin, Bureau of Economic Geology, Report of Investigations 192, 58 p.
Slade, R.M., Jr., Dorsey, M.E., and Stewart, S.L., 1986, Hydrology and water quality of the Edwards aquifer associated with Barton Springs in the Austin area, Texas: U.S. Geological Survey WaterResources Investigations Report 86-4036, 117 p.

- W.H. Asquith and M.O. Gary

Any use of trade, product, or firm names is for descriptive purposes only and does not imply endorsement by the U.S. Government.

\section{Information on technical reports and hydrologic data related to this study can be obtained from:}

Director

USGS Texas Water Science Center

8027 Exchange Dr.

Austin, TX 78754-4733

E-mail: dc_tx@usgs.gov

Phone: (512) 927-3500

FAX: (512) 927-3590

World Wide Web:

http://tx.usgs.gov/ 